\title{
下頻骨骨折におけろ lag screw 固定法の通応症
}

\author{
福田正・亮久田利弘・畐永和宏 \\ 山田長敬・入学陽一*
}

\section{Indication of Lag screw osteosynthesis in mandibule fractures}

\author{
Jinichi Fukuda - Toshihiro Kikuta - Kazuhiro Tominaga \\ Nagayoshi YAmada • Youichi NyugakU*
}

\begin{abstract}
Lag screw osteosynthesis is now performed in cases of an oblique fracture of the mandible divided buccal and lingual fragments.

Our 7 cases of mandibular oblique fractures were treated using the lag screw method. This article discusses the adaptation of this method.

An oblique fracture of the mandibular angle was shown in 4 cases, mandibular body in 2 cases and mental region in 1 case.

Osteosynthesis using 3 screws was performed to 2 cases of oblique fracture in the mandibular body and angle region. The other two cases of mandibular angle fracture were treated using 2 screws and a 2-hole-DC plate. A last case of mandibular angle fracture had only two screws with the rigid intermaxillary fixation for two weeks. The case with mental fractures was treated using with a rigid teeth arch -bar and a screws. The last case had one screw and a 6-hole-EDC plate.
\end{abstract}

The following results come from analysis of the post-operative courses of our 7 cases.

1. Three screws must be settled on the fracture surface area in a broad triangle.

2. In cases with a narrow fracture sufrace area, a good post-operative course can be expected if a adaptation of screw and plate is used.

3. Case with narrow fracture surface area in the post moral region must be settled by use of a couple of screw combined a 2-hole-DC plate on alveolus.

4. Case with narrow fracture surface area in the dental arch must be set by use of a couple of screw with rigid teeth arch-bar.

Key words: lag screw ostheosynthesis, oblique fracture, mandible

九州歯科大学口腔外科学第 1 講座

(主任：山田長敬教授)

*下関市立中央病院科

(主任 : 入学陽一)

First Department of Oral Surgery, Kyushu Dental College (Chief: Prof. Nagayoshi Yamada)

* Division of Dental, Shimonoseki Municipal Hospital (Chief: Youichi Nyugaku)

受付日：昭和62年 1 月 14 日
下顎骨骨折の骨内固定は鋼線や plate と screw によ るものが大部分である，特に最近では， plate による圧 迫骨接合術のみならず, mini plateによる片側の皮質骨 のみを利用した monocortical osteosynthesis がさん となってきた. しかし，下䫑骨骨折の中でも骨片が煩舌 側に分離した斜骨折に対しては, 骨の軸方向への王迫を 行う圧迫骨接合術では骨片の滑走といら結果をまねく． そこで Spiess1 $1^{1,2)}$, Schilli3,4), Niederdellmann ら5)はこ 
のような下顎骨斜骨折に対して lag screw による骨接 合術を行い良好な結果を得ると論じている。本邦では三 村ら ${ }^{6)}$, 池村ら ${ }^{7)}$ が本法に関する報告を行っている。

当科に执いても下顎骨斜骨折や顎変形症に拈ける下顎 枝矢状分割後の固定 ${ }^{8)}$ などに本法を行っている.

今回, 下顎骨斜骨折飞 Robert Mathys 社製 $\mathrm{AO}$ 小 皮質骨用ネジを使って lag screw による骨接合術を行 った症例について検討を加学干の知見を得たので報告 する。

症例

症例 $1 ：$ T.D. 15歳 男性.

階段で転倒, 左側オトガイ部を強打し, 左側下䋶骨体 部斜骨折と右側関節突起骨折を起こした症例である（写 真 1 ).

左側下顎骨体部骨折は， $\sqrt{3}$ 部煩側皮質骨から $\mid 56$ 間 を通って舌側皮質骨へ達していた。手術は口腔内から行 い, 頓側歯肉骨膜弁を広く形成し，骨折部を露出させた 後, 三内式線副子にて下䋶歯列を整復し䋶間固定を行っ

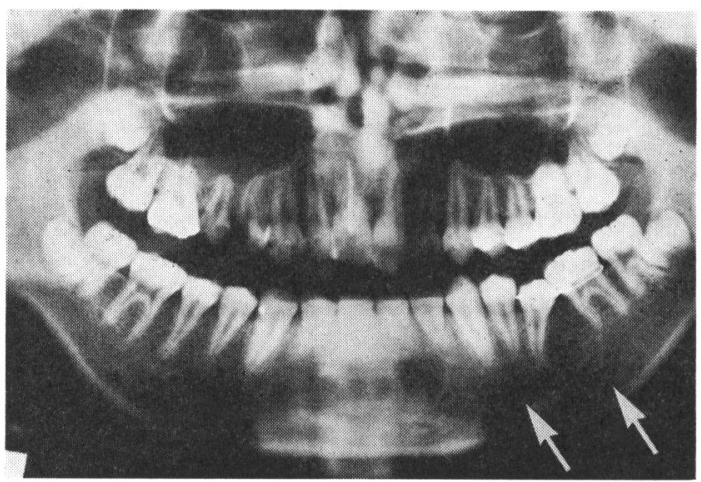

写真 1 症例 $1:$ 術前パノラマ $\mathrm{X}$ 線写真 矢印は斜骨折線を示吉。

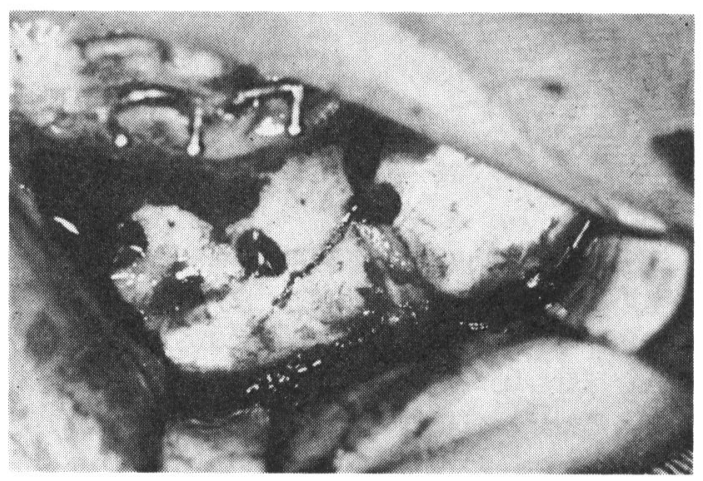

写真 2 症例 1 : 術中の骨折部所見 オトガイ孔を通る斜骨折を認める。
た。骨折部の偏位が少なかったため, 骨整復針子は使わ ずに, 大臼歯近心根前方で下顎管の上方拉よ゙下方, さ らにオトガイ孔の前方で下顎下縁付近の 3 か所を screw により固定を行った (写真 $2 \sim 4)$.

また右側関節突起骨折に対しては, 骨片の偏位が少な く, 若年秢のため保存的治療とし, 2 週間の顎間固定に よる局所安静の後, monoblockにて開口訓練を行った。

症例 2 : S.T. 17歳 男性.

交通事故により, 右側下顎骨体部骨折と左側下顎角部 斜骨折を起こした症例である(写真 5 ).

手術は口腔外から行い, 右側下顎骨体部は $\overline{43}$ 間に骨 折線を認めたため三内式線副子にて下顎の歯列を整復 し, 顎間固定後, 6-EDCP (AO plate) にて固定を行っ た.

また左側下顎角部は智歯の根尖から下顎角执よび第 2 大臼歯根尖に至る斜骨折を認めたため，まず智歯を抜歯 し, 抜歯窩を一次閉鎖後, 口腔外より下顎角部を露出さ せた。骨折は第 2 大且歯根尖付近の煩側皮質骨から智歯 を通って舌側皮質骨に至る広い骨折断面を呈していた。 そこで下顎管の下方を 3 個所 screwにより固定した。な

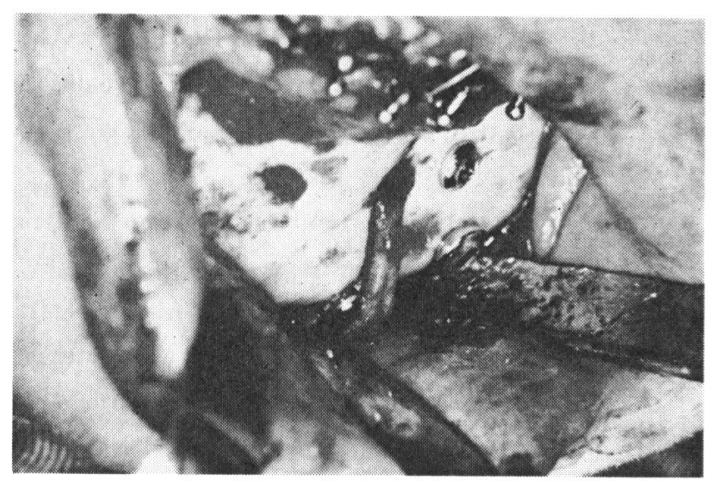

写真 3 症例 1 : 征中の骨折部所見 3 本のネジを認める。

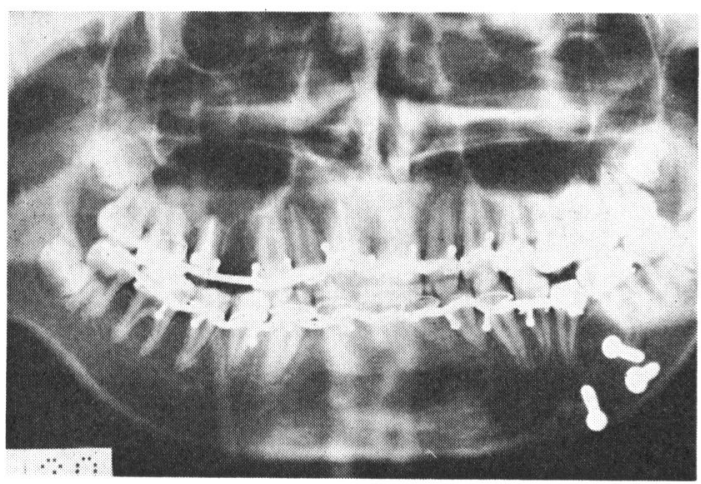

写真 4 症例 1 : 術後パノラマ $\mathrm{X}$ 線写真 


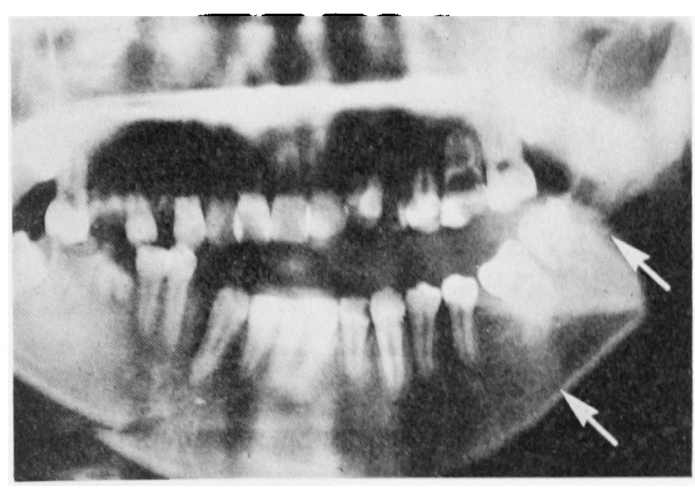

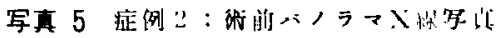

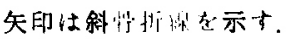

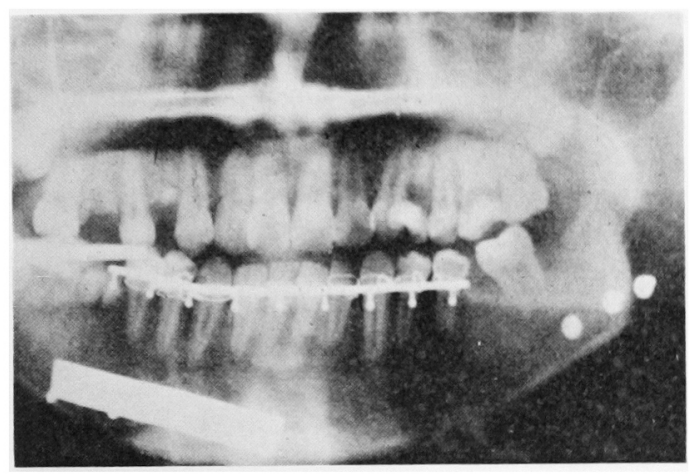

写真 6 症例 2 : 術後ハノラマ $\mathrm{X}$ 線写真

お顎間固定は手術終了後除去した（写真 6).

\section{症例 $3: \square 17$ 歳 男性.}

左倒下顎骨体部を手拳により数回眨打され，右側オト かイ部骨折と左側下顎角部斜骨折を起こした症例である (写真 7 ).

右側オトガイ部骨折は手術を口腔内から行い, $\overline{3} 2$ 間 の骨折のため三内式線副子にて下䫇荬列を整復後，顎間 固定を行い，骨折整復部を 6-EDCP (AO plate) にて 固定した。

一方，左側下顎角部の骨折は埋伏智菌の近遠心から， 近心側では下䫇骨体部に，遠心側では下䫛角に向かって 認められた。さらにこの骨折は智畨近心側の煩側皮質骨 から遠心側の舌側皮質骨に向から斜骨折として認められ た，そこで手術はます埋伏智雪を抜崡し，抜歯窩を一次 閉鎖した後に口腔外から行った，骨折断面はほぼ牙牙の 幅径程度であったため（写真 8)，下頡管下方を 2 か 所 screw により固定を行い，槽部は 2-DCP (AO plate) を使って monocortical osteosynthesis とした（写真 9 ， 10). そのため顎間固定は手術終了後に除去した。

症例 417 歳 男性.

野球の練習中に硬球を右側下顎骨体部に受け，右側才

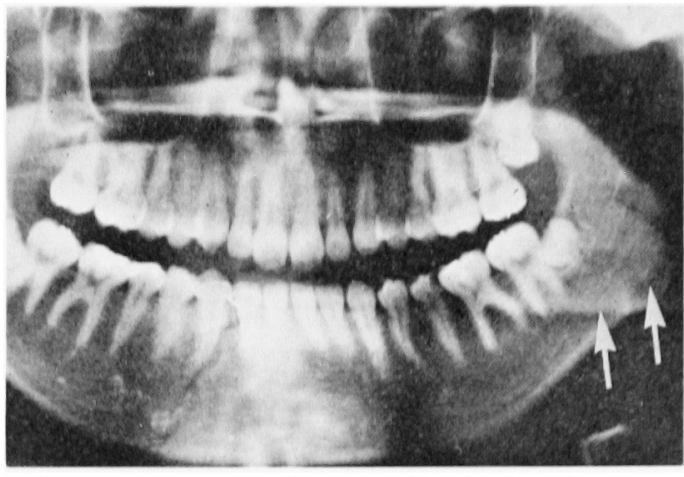

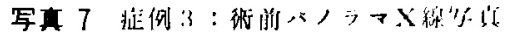
矢印和利骨折線を示す。

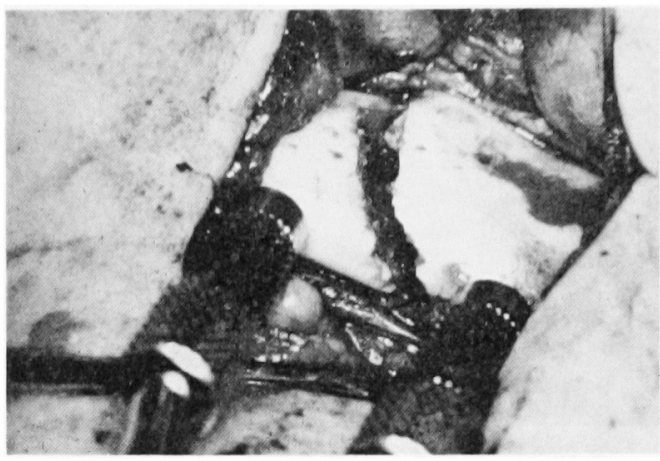

写真 8 症例 $3:$ 㭪中の骨折部所見

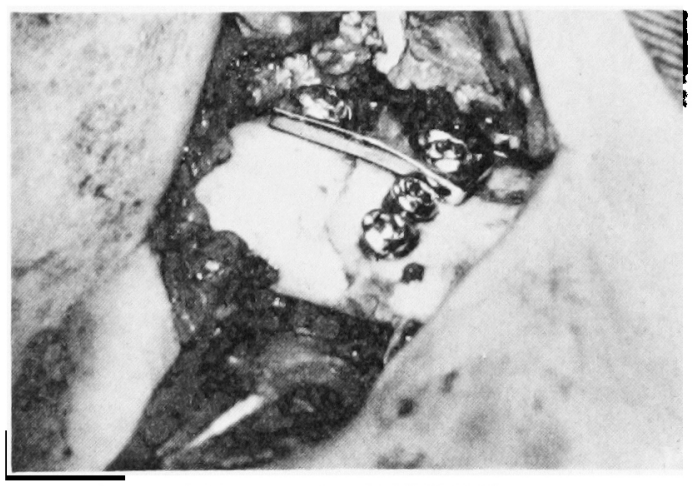

写真 9 症例 3 : 郝中の骨折部所見 2 本のネシとプレートの併用.

トガイ部骨折と右側下顎角部斜骨折を起こした症例であ る(写真11).

右側オトガイ部骨折は21!間の骨折として認められた ため，手術を口腔内から行った。まず骨折部を䈞出し， 三内式線副子による下顎歯列の整復と買間固定を行った 後, 下顎下縁を 4-DCP (AO plate) にて固定を行っ 


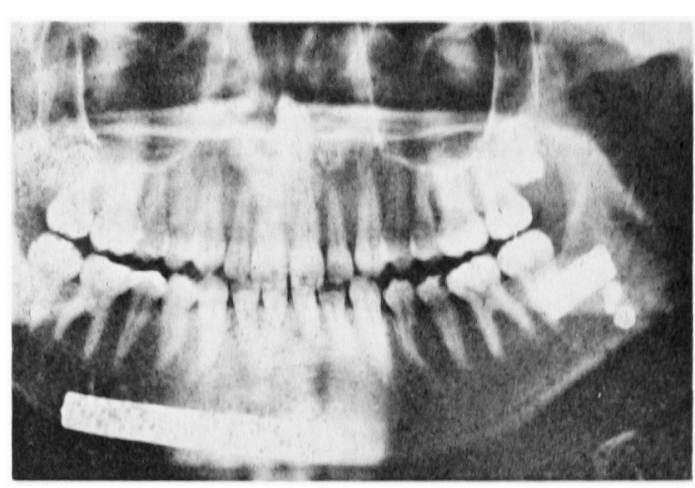

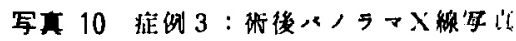

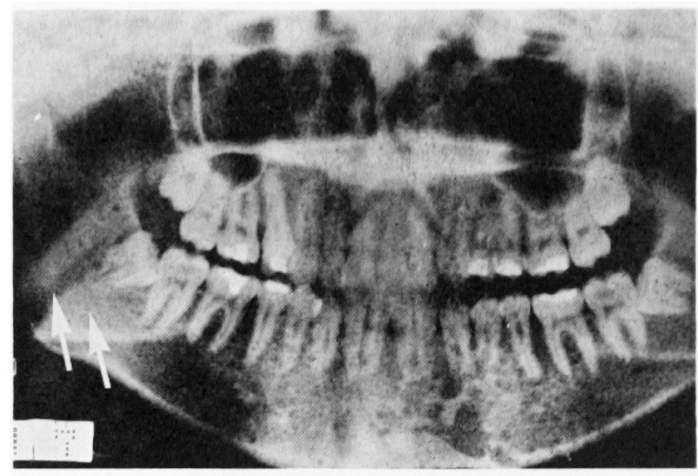

写真 11 店例 4 ：得前ハノラ 矢印は斜骨折を示す

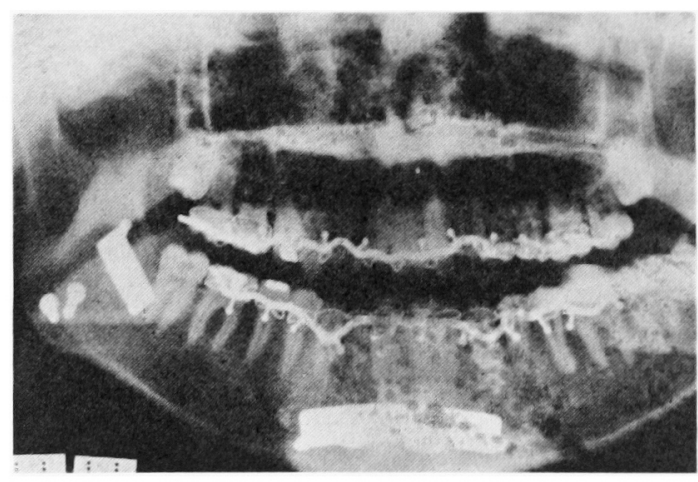

写真 12 症例 4 : 继後ハンラーX楾写真

た。

一方，右側下顥角部骨折は智歯根尖部から下䫑角に向 からわずかな骨折断面の斜骨折として認められた。手術 は埋伏智画を抜齿し，抜菌窩を一次閉鎖した後，口腔外 から行った，骨折断面が智畨の幅径より狭かったため， 下顎管の下方を 2 か所 screw で固定し，歯槽部を2DCP (AO plate) による monocortical ostheosynthesis

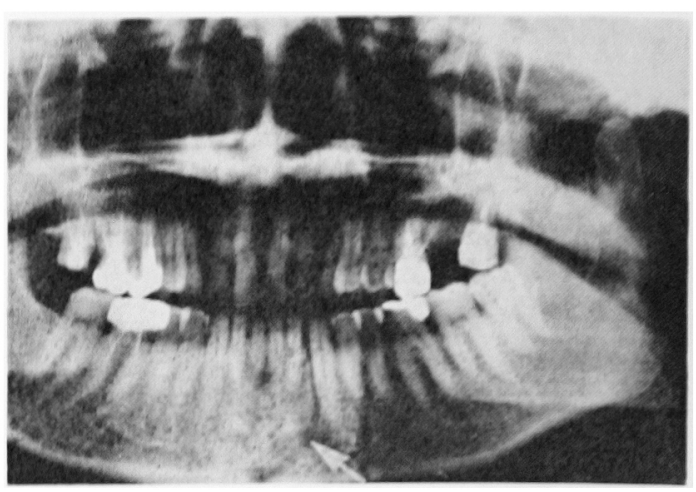

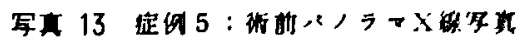
矢印以科量折学亦

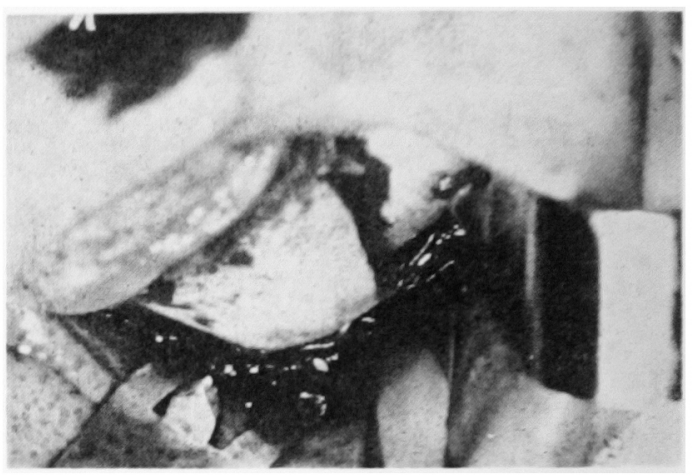

写直 14 征洌 5 : 得中の骨折部所見

とした。ナトガイ部の骨折部の固定を強固にするたの、

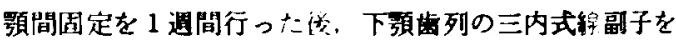
3 週間装着した（写重12）。

症例 $5:$ 43蔽 男性.

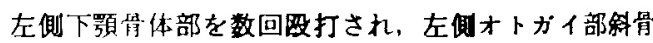
折と左側関節突起骨折を起こした症例である写直 13

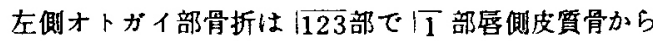
$\sqrt{3}$ 部舌側皮犋骨に至る科骨折であった（写真14：手術 は口然内から行い，骨折部を露出し，下頻柬列を三内式 線副子にて整得後，額間周定を行った，その後，骨折断 面がれ程広くないた放2 2 個所を screwで固定した（写 直 15

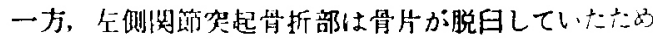
整復し， 5 穴の straight mini plate で固定した。

オトカイ部骨折の固定が screw 2 トとよったため， 下䫑此列の三内式線副子を術後 4 週間装着した。一方, 䫇間固定は 2 週間後に除去した（写真16）。

症例 $6: \square 16$ 歳男性.

両側煩部を手蒘で数回没打され，右側オトガイ部骨折 と左側下顎角部斜骨折を起こした症例である(写直17)

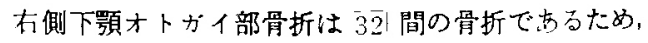




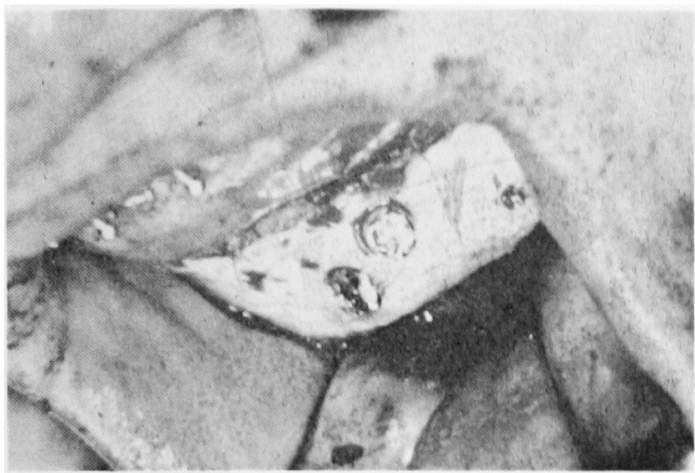

写莫 15 症例 5 : 得中の骨折部所見 2本の木ジれ䍐める。

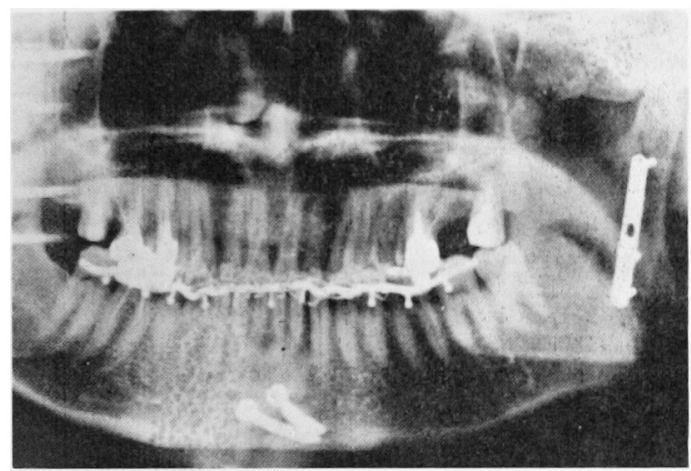

写真 16 症例 5 : 術後ハノラ

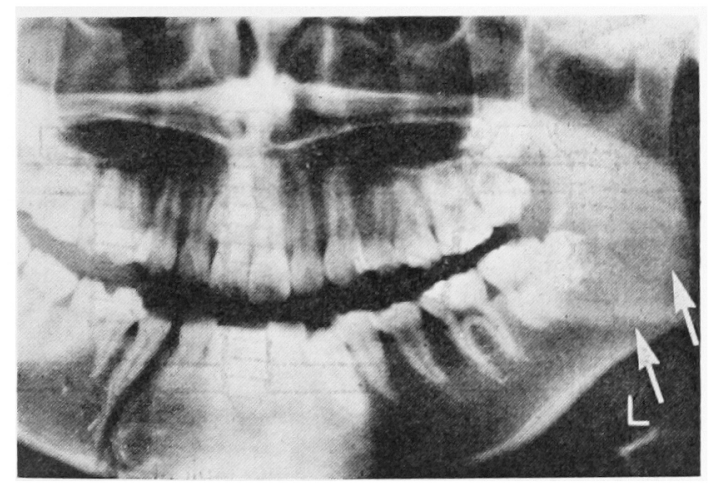

写真 17 症例 6 : 訹前ハノラ 矢印は斜骨折線を示す。

口腔内から骨折部を露出し，三内式線副子による下筼崡 列の整徣之䋶間固定を行った後，下䋶下縁を 4-DCP (AO plate) Rて固定した.

また左側下顎角部骨折は埋伏智歯を拔崡し，拔歯窩を 一次閉鎖した後，口腔外から行った。骨折は智幽近心側 の頓側皮質骨から遠心側の舌側皮質骨に向から斜骨折

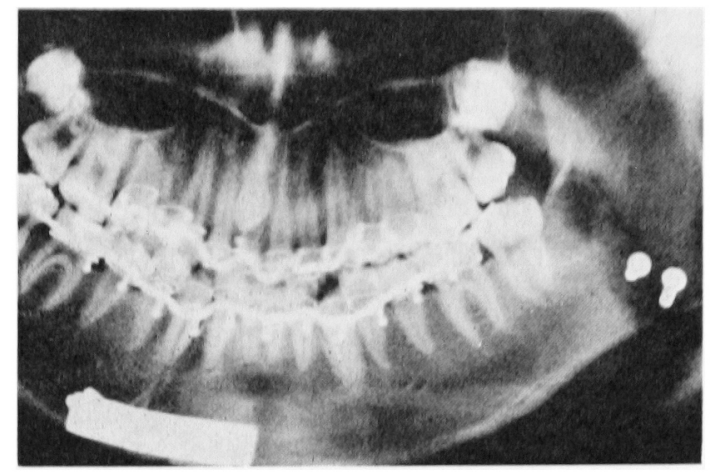

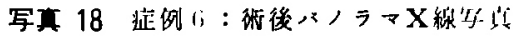

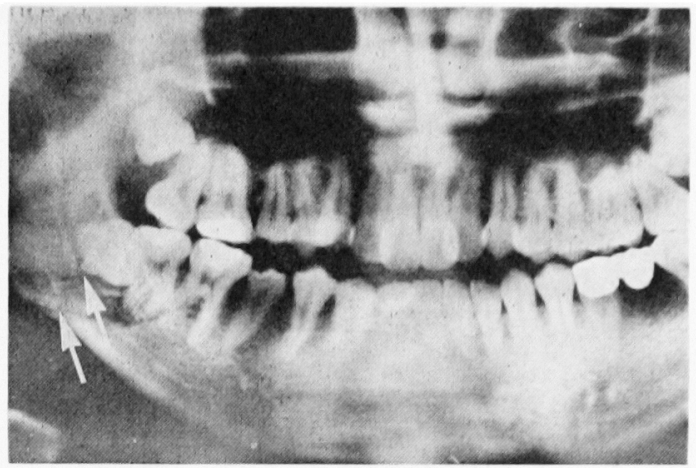

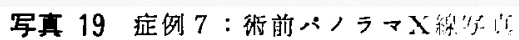
矢印は科骨折線を示す。

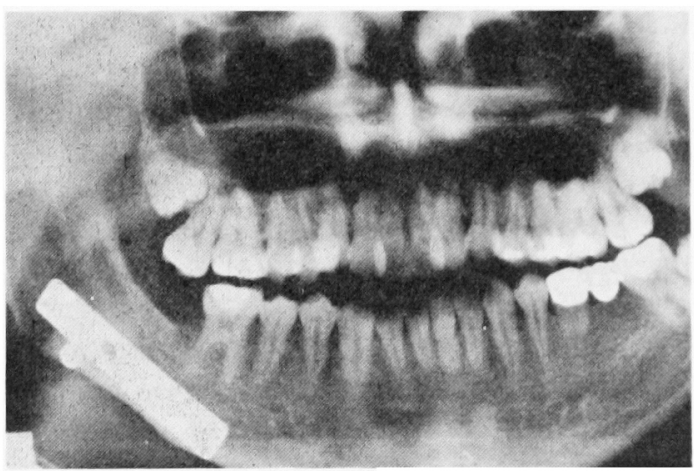

写真 20 症例 7 : 皘後ハノラマX線写真

で，智歯幅径よりやや広い面を呈していた。 そこで 2 個 所を screw Kて固定した (写真18).

下䫇角部の固定が screw 2 本のみとなったため顎間 固定を 2 週間行った。 またオトガイ部の固定が 4-DCP のため下顎歯列の三内式線副子は術後 4 週間装置した。 症例 $7: \square 18$ 歳 男性.

交通事故により，右側下顎骨体部斜骨折を起こした症 例である (写真19). 


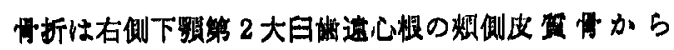

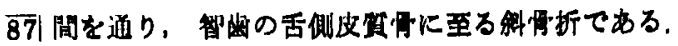

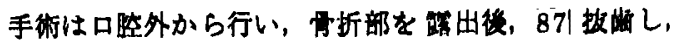

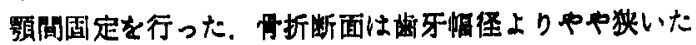
め plate Kよる压迫情接合術を予定したが，䉼断面 にずれが生したため 1 か所を screw にて固定し，その 後 6-EDCP (AO plate) にて下顆下悢を固定した。ま

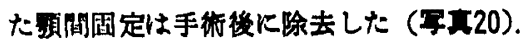

\section{考実}

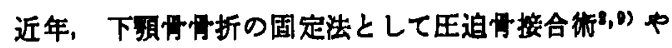
mini plate 利用した monocortical osteosynthesis ${ }^{10,11)}$ などがさかん使われている，王迫骨接合獄は一次骨治

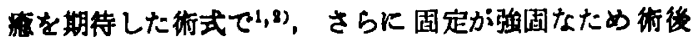
の頻間固定を必要としない利点を有していて，そのため 㭧者の精神的苦痛が少なく，早期社会復㛿が可能であ $3^{0,12)}$. 一方, mini plate を利用した monocortical osteosynthesis 江外側皮貫骨のみを利用する骨接合術のた め AO plate ゃ Luhr plate K比へててさく，柔㜞で あり，手術手技が容易である(1)などの特徵を有してい る.

しかしこれらの固定法は骨折断面が単純なるのにおい て応用可能となる。これは plate を用いた场合，压接 カが plate に平行，すなわち骨の長軸に平行に倬くか らである。このよらな plate Kよる固定を骨折線が科 走している圽合に使らと骨片の消走といら結果をまね く、そこで骨片が煩舌側に分離した骨折には lag screw とよる骨接合衍が有効となる。

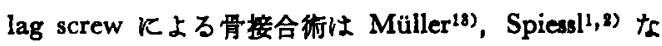
どよってその原理が諭じれ、Schillis,4), Niederdellmann ら5) などによってその症例が 報告されている.

これは screw をネジ山の切られた内側骨片に楴めつけ ることによって，外儧骨片と内側骨片が王迫され強固な 固定が得られるといらすのである（因 1 ).

lag screw Kよる骨接合術は一般には骨折断面の幅径 が広いものが適応となる。しかし骨折断面の幅径が歯牙 の幅径程度のすのもあり,これに対しては screwと plate の併用が行われる2,5) (因2).

一方, screw の刺入軸は骨折線に直角な線と煩側骨表 面の接線に直角な線とがなす角の二等分する方向であ る1,4)(图1)。これは骨折線值角の方向飞 screw 刺入，固定すると骨の長軸方向への負荷に耐えられずに 骨片にずれを生じるからである.

このような原理を有する lag screw 法による固定を 行った著者らの 7 症例について検討を加えてみる（表 1 ).

症例 1，2 はいずれす骨折断面の幅 径が広く, lag screw 法による固定が最適であった。 いずれの症例にお

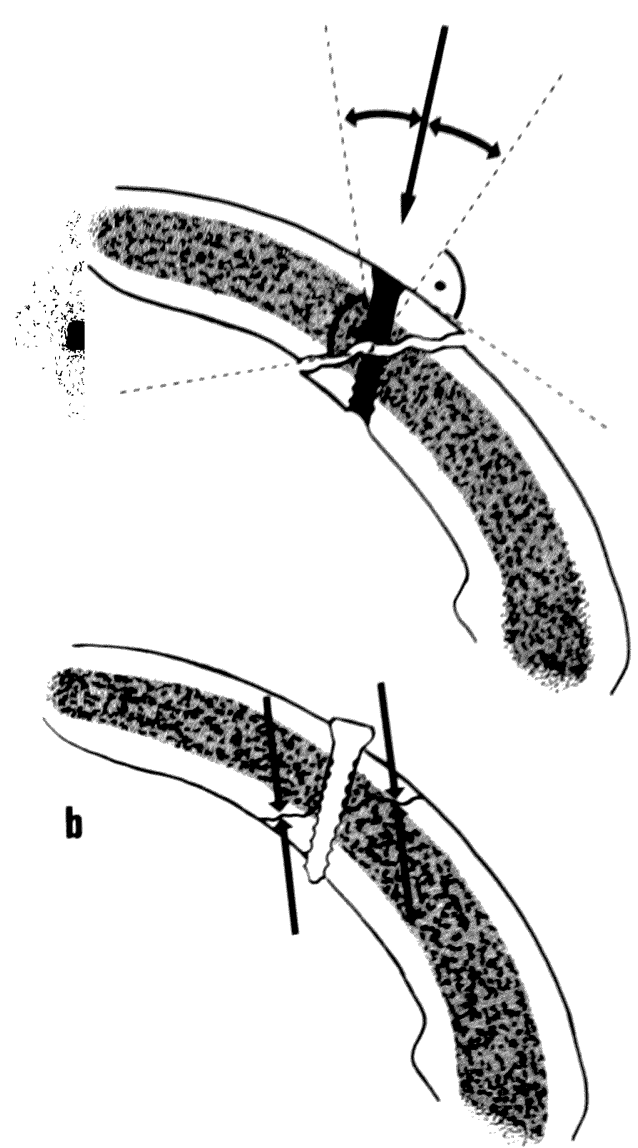

因 1 lag screw Кよろ固定の原理 (Spicad1) より 改变）

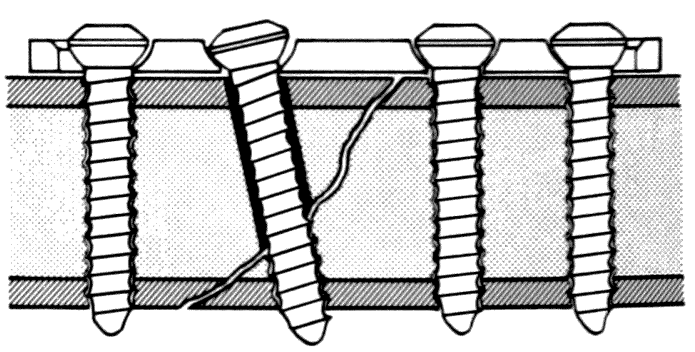

因 2 lag screw と plate の併用 (spiess!2) より改 変)

いても骨折断面が広かったため 3 本の screw による強 固な固定ができたのであるか，症例2で性 screw 除去 の祭に screw 周囲に著しい添加骨を認めた。これは症 例 1 では 3 本の screw が三角形を呈する面で固定され ていたのに対し, 症儌 2 では下䫑下限にはぼ一列に固定 されていたために骨のねしれに対し固定力が不足したも のと考える. 


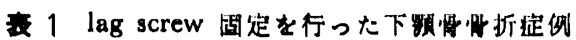

\begin{tabular}{|c|c|c|c|c|c|c|c|}
\hline 症例 & 名 助 & 年敞 & 性 & 原 & 因 & 骨折部位 & 边蓝. \\
\hline 1 & & 15 & $\hat{\sigma}$ & 忶 & 湖 & $\begin{array}{l}\text { 左䈐体部 } \\
\text { 右肉䬣英起 }\end{array}$ & $\begin{array}{l}3 \text { screw } \\
2 \text { W.I.M.F. }\end{array}$ \\
\hline 2 & & 17 & $\hat{\sigma}$ & \multicolumn{2}{|c|}{ 交通事故 } & $\begin{array}{l}\text { 左下筑角部 } \\
\text { 右情体部 }\end{array}$ & $\begin{array}{l}3 \text { screw } \\
6 \text {-EDCP }\end{array}$ \\
\hline 3 & & 17 & $\uparrow$ & 畩 & 打 & $\begin{array}{l}\text { 左下湿角部 } \\
\text { 右オトガイ部 }\end{array}$ & $\begin{array}{l}2 \text { screw +2-DCP } \\
\text { 6-EDCP }\end{array}$ \\
\hline 4 & & 17 & $\boldsymbol{\delta}$ & 打 & 揍 & $\begin{array}{l}\text { 右下影角部 } \\
\text { 右オカカイ 部 }\end{array}$ & $\begin{array}{l}2 \text { screw +2-DCP } \\
4-D C P+\text { arch bar }\end{array}$ \\
\hline 5 & & 43 & $\hat{\delta}$ & 略 & 打 & $\begin{array}{l}\text { 左オトガイ部 } \\
\text { 左闪飾实起 }\end{array}$ & $\begin{array}{l}2 \text { screw }+ \text { arch bar } \\
\text { straight mini plate }\end{array}$ \\
\hline 6 & & 16 & 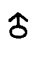 & 欧 & 打 & $\begin{array}{l}\text { 左下影角部 } \\
\text { 右オトガイ部 }\end{array}$ & $\begin{array}{l}2 \text { screw }+2 \text { W. I.M.F. } \\
\text { 4-DCP + arch bar }\end{array}$ \\
\hline 7 & & 18 & $\widehat{\delta}$ & 交通 & & 右骨体部 & 1 screw +6-EDCP \\
\hline
\end{tabular}

症例 3，4 は骨折部位が下題角部で，骨折断面が智采 の幅经か，それよりわずかに狭い程度であった。そこで これらの症例では下箦管より下方の位置を 2 本の screw で固定，さらに崡槽部を 2-DCP にて固定した。

これは骨接断面が狭く， screw 2 本分の面しかないた め, 固定力を增強させる目的で齿槽部を 2-DCP で固定 した.この際，plate の固定は外側皮質骨のみによる monocortical osteosynthesis で十分であった.

症例 5 では骨折断面がそれ程広くないため screw を 2 本使用した。そここで下額の齿列を整復固定していろ線 副子を訹後 4 週間併用した。

症例 6 は症例 3，4 亿類似した症例であったが，骨折 断面が他の症例より広かったことから screw 2 本のみ による固定とし、效間固定を 2 週間行った. しかし術後 10か月に screw 除去を行った際に screw 周囲に添加骨 を認めた.このことは, 骨折断面が歯牙幅径程度の場合 は screw 2 本による固定では固定力が不足することを示 唆していた。

症例 7 では骨折断面が著しく狭かったため plateによ る王迫骨接合術を試みたが骨片にずれを生じた。 そこで 下額下縁部を 1 個所 screw で固定した後に 6-EDCPに よる固定を行った。 また plate の選択は plate の装着 場所が下顓下緑になるため, 下影下绿の荤引力に対して 槽部では張力が生じ離開傾向が起こってくることか $ら$ EDCP (excentric dynamic complession plate) とし た.

このよらな lag screw による骨接合術の臨休経験か ら次のことが示唆された.

一般的に lag screw による骨接合術は骨折断面の幅 径が広いものが最適であり，3 本の lag screw にて強 固な固定が得られる. しかし骨のねじれに対する固定力 を強固にするため，3本の screw の位㯰関係ができる たけ広い三角形の面を呈するようにすることが必要であ 万(図3).

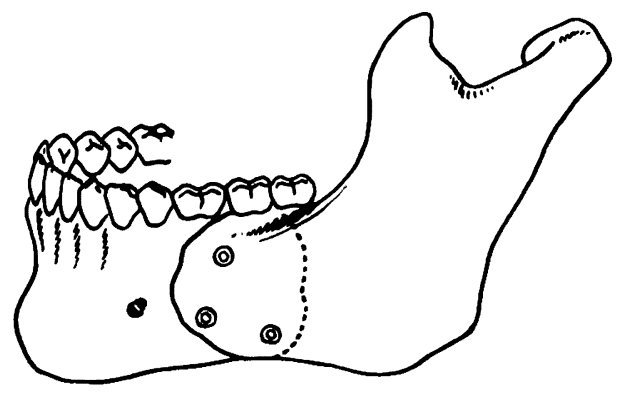

图33 本のネジによる固定

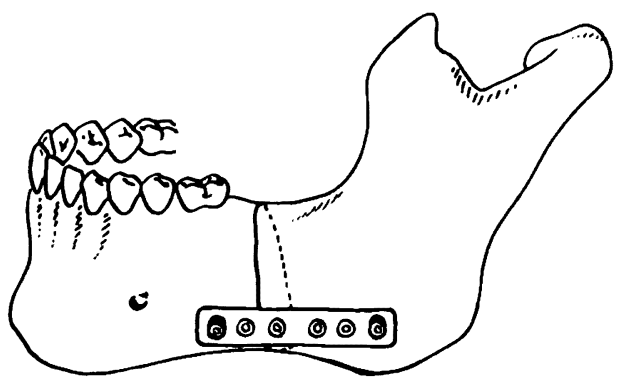

図 4 ネジとプレートの併用

次に骨折断面が歯牙の幅径程度か，それよりも狭いむ のに対しては plate や線幅子による歯列固定を併用する ことによって強固な固定が得られる。この場合併用する plate を下䫛下縁部に使ら場合と齿槽部に使ら場合とが ある，下䅡下绿部に固定する場合は，一般的な plate に よる王迫骨接合術にて骨折断面にずれを生じる場合に適 応する，すなわち lag screw により骨折断面を固定し， 強固な固定を得るために EDC plate を使用する。 その 時の固定は，下䫟下縁部での圧迫は必要ないので plate の中間部のネジの穴は central でよい. しかし両端のネ ジ穴は歯槽部を压迫するために excentric にする必要が 


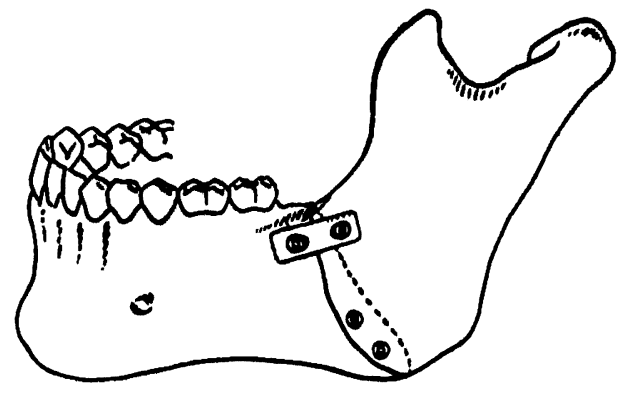

图 5 ネジとフレートの併用

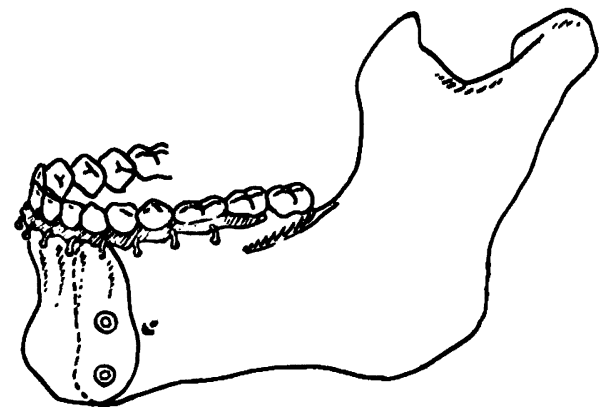

困 6 ネジと線副子の併用

ある（図 4)，一方，崡槽部に plate を併用するものは 骨折断面の幅径が雪牙の幅径程度のむので， 2 本の lag screw にて下額下縁が固定できた場合にさらに強固な固 定を得るために行ら. その時は plate を dynamic compression K固定を行らが, sciew は monocortical K固 定するたけけで十分にその役割をはたしらる（图５）。 ま た崡列を線副子により固定する場合は，骨折断面が広く ないが，骨折線が多数の雪牙の間にあり，崡槽部を齿列 固定により強化できる場合に使用する（図 6).

screw 除去の時期は術後 1 年以内が妥当である.これ は screw の材質が AO plate の材質と同じで，不銹銅 とチタンとから成っていて, Metallosis を起こしにく いかからである．さらに臨床的にも異常がないといら報 告む散見されるき,12)．そこで著者らはscrew を術後半年 から 1 年以内に除去するよらにしている.

最後に, lag screw による固定は皮们切開が少なくて すみ，骨片がずれることがなく， plate にくらべて操作 が簡単で，鋼線にくらぺて固定が強固であることが明ら かとなった.

今後, lag screw 固定法と他の固定法を併用すること により，より広範囲な症例に適応できると思われる。

結 語

下䫇骨斜骨折に対し lag screw 固定法を行った症例
そついて柃搏を加え，次のよろな結果を得た。

一般的に lag screw Kよる骨接合衍は，角折断面が広 いものに対し screw にて固定を行ろ方法であるか，こ の際，3本の screw の位值咸保ができるだけ広い三角 形の面を量するよ5に固定する心要がある。

解折断面が藉しく涨いるのでは， lag screw 固定と

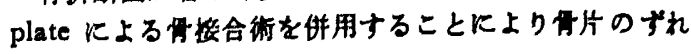
を防止することがでる。

骨折断面が涨くても，2 本の lag screw 固定かi可能な ら梅棈部に 2 穴の DC plateを併用することにより㟋固 な固定が行られる。

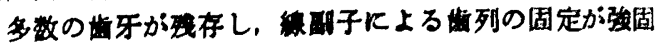
に得られるならば2 本の lag screw 固定と併用するこ とが可能である。

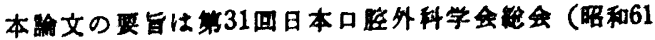

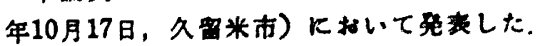

\section{引用女 辝}

1) Spiessl, B.: Spezielle Frakturen- und Luxationslehre. Band I Gesichtsschädel, Georg Thieme Verlag, Stuttgart, 1972, p 93-96.

2) Spiessl, B.: New concept in maxillofacial bone surgery. Springer-Verlag, Berlin-Heidelberg-New York, 1976, p 53-58, 115-122.

3) Schilli, W.: Compression ostcosynthesis. J Oral Surg 35: 802-808 1977.

4) Schilli, W. und Niederdelmann, H.: Aktuelle Probleme in Chirurgie und Orthopadie. Verletzungen des Gesichtsschädels, Verlag Hans Huber, Bern-Stuttgart-Wien, 1980, p 33-34.

5) Niederdellmann, H., Akuamoa-Boating, E., et al.: Lag-screw osteosynthesis: a new procedure for treating fractures of the mandibular angle. $J$ Oral Surg 39: 938-940 1981.

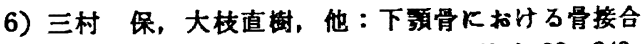

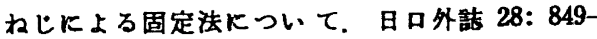
8571982.

7）池村邦男，日高英治，他：Lag screw Kより固定 を行った下穎骨骨折の 1 例. 日口外誌 30：193819431984.

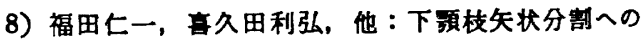
セラミックスネジ止め固定法に圆する漹床的㛟 討. 九州齿会諗 38: 919-928 1984.

9）瀬戸晥一，尾口志: 穎骨整愎, 固定法の進歩. 科ジャーナル 22: 163-169 1985.

10) Champy, M., Lodde, J.P., et al.: Mandibular osteosynthesis by miniature screwed plates via a buccal approach. J maxfac Surg 6: 14-21 1978.

11）池村邦男, 三宅正輝, 他：ミニプレートによる下

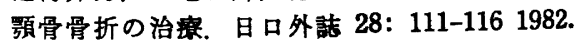


12）番月武，掼量昌昭，他：A.O. Osteosynthese

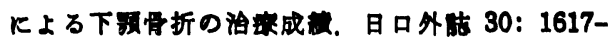
16231984.
13) Muller, M.E., Allogbwer, M., et al.: Manual of internal fixation. 2nd Ed, Springer-Verlag, Berlin, 1979, p 32-41. 